\title{
Faktor Kriminologi Narapidana Residivis Pencurian di Lembaga Pemasyarakatan Kelas II B Kota Tasikmalaya
}

\author{
Yola Karelina*, Muh. Endriyo Susila \\ Fakultas Hukum, Universitas Muhammadiyah Yogyakarta \\ *Korespondensi : ${ }^{*}$ yola.karelina.2016@law.umy.ac.i
}

Info Artikel
$\begin{array}{ll}\text { Riwayat: } & \\ \text { Diajukan } & : 28 \text { Mei } 2021 \\ \text { Ditelaah } & : 31 \text { Mei } 2021 \\ \text { Direvisi } & : 31 \text { Mei } 2021 \\ \text { Diterima } & : 02 \text { Juli } 2021\end{array}$

Kata Kunci :

analisis kriminologi; pencurian; residivis

DOI:

10.18196/ijclc.v2i2.12422

\begin{abstract}
Abstrak
Tindak pidana pencurian merupakan tindak pidana yang sering terjadi dalam masyarakat. Sebagian pelaku bahkan menganggap pencurian merupakan pekerjaannya. Karena sanksi yang diberikan kurang memberikan efek jera, banyak pelaku tindak pidana pencurian mengulangi perbuatannya atau disebut juga residivis. Penelitian ini menjelaskan tentang faktor-faktor yang menyebabkan terjadinya pengulangan tindak pidana pencurian dan bagaimana pembinaan terhadap narapidana residivis pencurian di Lembaga Pemasyarakatan Kelas IIB Kota Tasikmalaya. Penelitian yang bersifat yuridis empiris ini menggunakan data primer dan data sekunder. Pengambilan data dilakukan dengan studi kepustakaan dan studi lapangan. Hasil penelitian menunjukkan bahwa faktor utama penyebab terjadinya pengulangan tindak pidana pencurian di Lembaga Pemasyarakatan Kelas IIB Kota Tasikmalaya adalah faktor ekonomi. Terkait pembinaan terhadap narapidana residivis pencurian, tidak ada perbedaan khusus. Sama halnya dengan narapidana umumnya, pembinaan terhadap narapidana residivis pencurian di Lembaga Pemasyarakatan Kelas IIB Kota Tasikmalaya dilakukan berdasarkan Peraturan Pemerintah Nomor 58 Tahun 1999 tentang Syarat-syarat dan Tata Cara Pelaksanaan Wewenang, Tugas dan Tanggungjawab Perawatan Tahanan.
\end{abstract}

\section{Pendahuluan}

Pesatnya perkembangan dan perubahan zaman saat ini menimbulkan berbagai dampak, baik secara positif maupun negatif. Salah satu dampak negatif dari perkembangan zaman adalah munculnya berbagai macam bentuk kejahatan. Kejahatan dapat terjadi di manapun, kapanpun, dan pada siapapun. Salah satu kejahatan yang sering terjadi adalah pencurian. Berdasarkan Statistik Kriminal tahun 2018, Polri mencatat sekitar 107.042 kejahatan terhadap hak milik/barang tanpa kekerasan. ${ }^{1}$ Kejahatan pencurian merupakan kejahatan yang paling banyak terjadi pada desa/kelurahan di Indonesia, jumlahnya mencapai lebih dari 36-45\% dari seluruh desa. Persentase desa yang mengalami kejadian pencurian meningkat dari 2011 yang awalnya 36,78\% menjadi 41,05\% pada 2014. Sementara pada tahun 2018 meningkat kembali menjadi $45,01 \% .^{2}$

Banyak faktor yang melatarbelakangi terjadinya pencurian. Faktor tersebut antara lain, berkaitan dengan kemampuan ekonomi masyarakat yaitu pendapatan yang kurang mencukupi sehingga tidak dapat menutupi kebutuhan hidup, tingkat pendidikan yang rendah dan keadaan di mana tingkat penduduk lebih tinggi daripada lapangan pekerjaan, hal ini dapat berpotensi menimbulkan perilaku kriminal dalam masyarakat, tak terkecuali pencurian itu sendiri. ${ }^{3}$ Hal tersebut menggambarkan bahwa kejahatan sebagai

1 Badan Pusat Statistik. Statitik Kriminal. (2018). Diakses pada tanggal 10 Oktober 2019, https://www.bps.go.id/publication/download.html,

${ }^{2}$ Ibid,

${ }^{3}$ Andre, K.H. (2019). Peran Kejaksaan dalam Penuntutan Tindak Pidana Pencurian dengan Kekerasan (Skripsi). Universitas Lampung, Indonesia. h. 3 
suatu kendala dalam masyarakat (crime in society) yang senantiasa terkait pada proses-proses ekonomi yang begitu mempengaruhi kehidupan manusia. ${ }^{4}$

Faktor yang mempengaruhi seseorang melakukan suatu kejahatan sebenarnya dapat di lihat dari berbagai teori penyebab terjadinya kejahatan dalam ilmu kriminologi. Kriminologi sangat erat kaitannya dengan hukum pidana sekalipun masing-masing memiliki fungsinya sendiri. Hukum berfungsi sebagai bentuk perlindungan kepentingan manusia, sehingga sudah sewajarnya jika hukum harus dilaksanakan secara normal, damai, dan hukum harus memberikan efek jera terhadap orang yang melanggarnya. ${ }^{5}$ Meski demikian penegakan hukum di Indonesia masih terdapat beberapa ketimpangan serta peristiwa pelanggaran hukum lainnya dengan angka relatif tinggi. Salah satu faktor yang menjadikan hal tersebut terjadi salah satunya adalah lemahnya pemberian sanksi atau hukuman bagi pelaku tindak pidana.

Pemberian sanksi terhadap pelaku tindak pidana di Indonesia hanya bersifat memberikan rasa "malu", bukan memberikan efek "jera". ${ }^{6}$ Tidak mengherankan jika banyak orang yang melakukan tindak pidana berulang atau disebut residivis. Residivis diartikan sebagai orang yang pernah dihukum kemudian mengulangi tindak kejahatan yang sama atau biasa disebut penjahat kambuhan. ${ }^{7}$ Banyaknya kasus residivis pencurian disebabkan adanya berbagai faktor, salah satunya faktor ekonomi. Hukum pidana sendiri selama ini hanya berfokus terhadap cara penyelesaian tindak pidana yang telah terjadi, bukan untuk mengetahui cara mencegah tindak pidana tersebut agar tidak terjadi kembali sehingga kasus residivis pencurian masih banyak dilakukan.

Salah satu contoh kasus pencurian yang bersifat residivis sebagaimana yang terdapat dalam Putusan Pengadilan Tasikmalaya nomor register perkara 223/Pid.B/2019/Pn.Tsm dengan terdakwa yang bernama DAK. Terdakwa di dakwa oleh penuntut umum dengan dakwaan tunggal yaitu pasal 363 Ayat (1) ke-3 dan ke-5 KUHP Jo Pasal 65 ayat (2) KUHP. Pertimbangan putusan dari Majelis Hakim di dasarkan pada keadaan memberatkan dan meringankan terdakwa. Salah satu keadaan yang memberatkan terdakwa yaitu terdakwa pernah dihukum sebelumnya. Dalam putusannya hakim memutuskan terdakwa terbukti secara sah dan meyakinkan bersalah melakukan tindak pidana pencurian dalam keadaan memberatkan yang dilakukan beberapa kali sebagaimana dalam dakwaan tunggal yaitu pasal 363 ayat (1) ke-3 dan ke-5 KUHP jo pasal 65 ayat (2) KUHP dan memberikan sanksi pidana penjara selama 2 tahun 4 bulan. $^{8}$

Pasca putusan pengadilan yang dijatuhkan oleh Hakim, maka terdakwa akan menjalani hukuman di Lembaga Pemasyarakatan. Lembaga Pemasyarakatan merupakan suatu sistem yang mengatur mengenai perlakuan terhadap warga binaan pemasyarakatan berdasarkan ketentuan Undang-undang Nomor 12 Tahun 1995 Tentang Pemasyarakatan. ${ }^{9}$ Eksistensi Lembaga Pemasyarakatan sangat penting bagi proses pemulihan terdakwa dan dijadikan sebagai institusi yang bertujuan untuk meminimalisir kecenderungan seorang pelaku kejahatan untuk mengulangi kejahatannya, salah satunya melalui upaya pembinaan narapidana. Mengingat banyaknya kasus residivis yang masih terjadi memunculkan persoalan bagaimana implementasi dan efektifitas pembinaan terhadap warga binaan selama ini. Apakah terdakwa residivis mendapatkan perlakuan yang berbeda dalam hal pembinaan, atau diperlakukan sama dengan terdakwa lainnya yang baru melakukan tindak pidana untuk yang pertama kalinya. Berdasarkan hal tersebut, penulis merasa tertarik untuk mengetahui faktor penyebab residivis melakukan pencurian dan bagaimana pembinaan terhadap narapidana tersebut selama menjalani hukuman di Lembaga pemasyarakatan.

\footnotetext{
${ }^{4}$ Adang, Y.A. (2013). Kriminologi. Bandung: Refika Aditama. h. 37.

${ }^{5}$ Mertokusumo, S. (2007). Mengenal Hukum Suatu Pengantar. Yogyakarta: Liberty Yogyakarta. h. 160.

${ }^{6}$ Afamery, S.S. (2016). Residivis dalam Presfektif Sosiologi Hukum. Jurnal Hukum Volikgeist, 1(1). h.105.

${ }^{7}$ Ibid, h. 107

${ }^{8}$ Putusan Pengadilan Negeri Tasikmalaya Nomor: 223/Pid.B/2019/Pn.Tsm.

${ }^{9}$ Rahmad, A dkk. (2016). Tugas dan Wewenang Lembaga Pemasyarakatan Ambarawa dalam Pembinaan Narapidana Sebagai Wujud Perlindungan Narapidana Sebagai Warga Negara. Diponegoro Law Journal, 5(3). h. 3.
} 


\section{Metode Penelitian}

Penelitian ini yang bersifat yuridis empiris dengan mengkaji ketentuan hukum yang berlaku terkait pembinaan narapidana dan pelaksanaannya di Lembaga Pemasyarakatan Kelas IIB Kota Tasikmalaya. Bahan-bahan penelitian baik yang berupa data primer maupun data sekunder diperoleh dari penelitian lapangan dan penelitian kepustakaan. Data yang diperoleh baik dari studi kepustakaan maupun dari penelitian lapangan akan dianalisis secara deskriptif kualitatif dengan mengelompokkan dan menyelesaikan data yang didapat dari teori-teori, asas-asas, dan kaidah-kaidah hukum yang diperoleh dari studi pustaka dan akan dihubungkan dengan data yang didapat dari lapangan sehingga memperoleh jawaban dari permasalahan yang dirumusakan.

\section{Hasil dan Pembahasan}

\subsection{Faktor Penyebab Terjadinya Tindak Pidana Pencurian yang Dilakukan Oleh Residivis Pencurian di Lembaga Pemasyarakatan Kelas IIB Kota Tasikmalaya}

Pengertian tindak pidana dalam Kitab Undang-undang Hukum Pidana (KUHP) dikenal dengan istilah strafbaarfeit, dan dalam kepustakaan hukum pidana sering mempergunakan istilah delik. Sedangkan dalam pembuatan undang-undang menggunakan istilah peristiwa pidana atau perbuatan pidana atau tindakan pidana. ${ }^{10}$ Tindak pidana pencurian merupakan tindak pidana yang sering terjadi. Ringannya hukuman yang dijatuhkan membuat para pelaku tidak merasa jera sehingga memicu mereka untuk melakukan pencurian lagi yang disebut dengan residivis. Residivis adalah seseorang yang mengulangi perbuatan pidana sesudah dijatuhi pidana dengan keputusan hakim yang mempunyai kekuatan hukum tetap karena perbuatan pidana yang telah dilakukanya lebih dahulu. ${ }^{11}$ Dalam Kitab Undang-undang Hukum Pidana residivis diatur pada BAB XXXI Aturan tentang Pengulangan Kejahatan yang Bersangkutan dengan Berbagai Bab pada pasal 486, pasal 487, dan pasal 488.

Berdasarkan isi dari pasal 486, pasal 487, dan pasal 488 KUHP menyatakan bahwa "Sejak menjalani untuk seluruhnya atau sebagian dari pidana penjara yang dijatuhkan kepadanya", maksud dari kalimat sejak menjalani seluruhnya adalah bahwa narapidana telah menjalani seluruh masa tahanannya dan telah keluar dari Lembaga Pemasyarakatan, kemudian ia melakukan tindak pidana kembali. Sementara maksud dari kalimat sejak menjalani sebagian dari pidana penjara yang dijatuhkan kepadanya, yaitu bahwa narapidana selama masa tahanannya melakukan perbuatan pidana kembali.

Banyaknya narapidana residivis dapat terlihat dalam data narapidana residivis pencurian di Lembaga Pemasyarakatan Kota Tasikmalaya sebagaimana tersaji dalam tabel. 1. Sedangkan Untuk mengetahui faktor penyebab terjadinya para narapidana residivis melakukan pencurian penulis melakukan wawancara kepada 5 orang narapidana residivis pencurian di Lembaga Pemasyarakatan Kota Tasikmalaya. Hasil dari wawancara tersebut tersaji dalam tabel. 2

Berdasarkan hasil wawancara dengan responden, menunjukkan bahwa residivis akan mendapatkan pemberatan sepertiga dari hukumannya terdahulu. Berdasarkan tabel di atas, dapat diketahui bahwa semua responden memiliki alasan yang sama untuk melakukan pencurian berulang, yaitu sama-sama terdesak karena faktor ekonomi. Hal tersebut selaras dengan teori kriminologi sosiologis, di mana perlakuan jahat diperoleh dari pengaruh yang terdapat dari luar diri perilaku. Salah satunya yaitu adanya desakan ekonomi, sehingga seseorang yang merasa terdesak dapat melakukan tindak pidana kejahatan seperti pencurian.

Faktor lainnya disebabkan karena faktor eksternal yang berasal karena adanya cap dari masyarakat. Respoden 1, 2, dan 3 menyatakan bahwa cap jelek dari masyarakat terhadap mereka yang berstatus sebagai narapidana membuat diri responden tertekan dan merasa sudah tidak bisa hidup normal di masyarakat. Mereka akhirnya memutuskan untuk melakukan tindak pidana pencurian lagi, dan tidak masalah jika harus kembali di hukum dan menjalani hukuman di Lembaga Pemasyarakatan. Bahkan menurut mereka, Lembaga Pemasyarakatan menjadi tempat yang lebih nyaman karena mereka dapat

${ }^{10}$ Ilyas, A. (2012). Asas-asas Hukum Pidana. Yogyakarta: Rangkang Education Yogyakarta \& PUKAPIndonesia. h. 18.

${ }^{11}$ Ali,M. (2011). Dasar-dasar Hukum Pidana. Jakarta: Sinar Grafika. h. 196. 
berbaur dengan napi lain tanpa mendengar cap jelek atau stigma seperti yang mereka rasakan ketika berada di tempat tinggalnya. Adanya cap jelek atau labelling dari masyarakat ini yang menyebabkan responden melakukan tindak pidana berulang. Respon yang berbeda dirasakan oleh Responden 4 dan 5, meskipun masyarakat menstigma dan memberikan cap jelek, mereka mengabaikannya dan menganggap hal tersebut merupakan hal yang biasa. Mereka tetap dapat menjalani hidup di masyarakat dengan normal, hanya saja faktor ekonomi yang belum bisa dihindari sehingga mereka masih melakukan pencurian lagi.

Tabel 1. Daftar Narapidana Residivis Pencurian Lembaga Pemasyarakatan Kota Tasikmalaya

\begin{tabular}{|c|c|c|c|c|}
\hline No & $\begin{array}{l}\text { No. Reg } \\
\text { Instansi }\end{array}$ & Nama & Alamat & $\begin{array}{c}\text { Tempat Tanggal } \\
\text { Lahir }\end{array}$ \\
\hline 1 & B I 134/19 & $\begin{array}{l}\text { Andri Irawan Bin } \\
\text { Daru }\end{array}$ & $\begin{array}{l}\text { Dusun Sukawangi Rt. } 15 \text { Rw. 04, } \\
\text { Pasirpanjang, Manonjaya Kab. } \\
\text { Tasikmalaya }\end{array}$ & $\begin{array}{l}\text { Tasikmalaya, } \\
25 / 12 / 1994\end{array}$ \\
\hline 2 & B I 90/18 & Ridwan Bin Enceng & $\begin{array}{l}\text { Kp. Cikaret Rt. } 04 \text { Rw. } 02 \text { Cikalong, } \\
\text { Cikalong, Kab.Tasikmalaya }\end{array}$ & $\begin{array}{l}\text { Tasikmalaya, } \\
04 / 10 / 1995\end{array}$ \\
\hline 3 & B I 98/18 & $\begin{array}{l}\text { Agus Triana Bin Uus } \\
\text { Usman }\end{array}$ & $\begin{array}{l}\text { Kp. Lampegan, Margalaksana, Sukaraja, } \\
\text { Kab.Tasikmalaya }\end{array}$ & $\begin{array}{l}\text { Tasikmalaya, } \\
02 / 05 / 1992\end{array}$ \\
\hline 4 & B I 186/18 & $\begin{array}{l}\text { Dede Sobari Bin } \\
\text { Toto }\end{array}$ & $\begin{array}{l}\text { Kp. Cijolang Rt. } 08 \text { Rw. 03, Margalaksana, } \\
\text { Sukaraja, Kab.Tasikmalaya }\end{array}$ & $\begin{array}{l}\text { Tasikmalaya, } \\
05 / 04 / 1978\end{array}$ \\
\hline 5 & B I 08/19 & Mustopo Bin Solihin & $\begin{array}{l}\text { Cikunten Indah Rt. } 05 \text { Rw. } 012 \\
\text { Sambongjaya, Mangkubumi, Kota } \\
\text { Tasikmalaya }\end{array}$ & $\begin{array}{l}\text { Tasikmalaya, } \\
06 / 06 / 1991\end{array}$ \\
\hline 6 & B I $226 / 18$ & $\begin{array}{l}\text { Dani Muhamad Bin } \\
\text { Dedi }\end{array}$ & $\begin{array}{l}\text { Kp. Nagrog Rt.03 Rw.09 Padasuka, } \\
\text { Sukarame, Kab.Tasikmalaya }\end{array}$ & $\begin{array}{l}\text { Tasikmalaya, } \\
26 / 06 / 1996\end{array}$ \\
\hline 7 & B I 25/19 & $\begin{array}{l}\text { Bayu Anggara Bin } \\
\text { Dedi }\end{array}$ & $\begin{array}{l}\text { Kp. Tonjong Rt. } 21 \text { Rw. } 06 \text { ds. Janggala, } \\
\text { Sukaraja, Kab. Tasikmalaya }\end{array}$ & $\begin{array}{l}\text { Tasikmalaya, } \\
13 / 04 / 1999\end{array}$ \\
\hline 8 & B I $60 / 19$ & $\begin{array}{l}\text { Destra Asmara Bin } \\
\text { Memed Mulyadi }\end{array}$ & $\begin{array}{l}\text { Kp. Garunggang Rt. } 27 \text { Rw.06 Pasirsalam, } \\
\text { Mangunreja Kab. Tasikmalaya }\end{array}$ & $\begin{array}{l}\text { Tasikmalaya, } \\
26 / 11 / 1994\end{array}$ \\
\hline 9 & B I 95/19 & Eriyanto Bin Dindin & $\begin{array}{l}\text { Kp. Cikangkareng Rt.01 Rw.07 } \\
\text { Hergarwangi, Bantarkalong Kab. } \\
\text { Tasikmalaya }\end{array}$ & $\begin{array}{l}\text { Kab.Tasikmalaya, } \\
\text { 23/07/1997 }\end{array}$ \\
\hline 10 & B I 96/19 & $\begin{array}{l}\text { Muhammad } \\
\text { Arifyansyah Bin } \\
\text { Sarlan }\end{array}$ & $\begin{array}{l}\text { Kp. Pangkalan Rt.03 Rw.07 Semanan, } \\
\text { Kalideres, Kota Jakarta Barat }\end{array}$ & $\begin{array}{l}\text { Jakarta, } \\
\text { 28/06/1998 }\end{array}$ \\
\hline 11 & B I 99/19 & $\begin{array}{l}\text { Ahmad Toni Irawan } \\
\text { Bin H. Uhud (Alm) }\end{array}$ & $\begin{array}{l}\text { Kp. Babakan Asri Rt.02, Rw.06 Tanjung, } \\
\text { Kawalu, Kota Tasikmalaya }\end{array}$ & $\begin{array}{l}\text { Tasikmalaya, } \\
07 / 12 / 1972\end{array}$ \\
\hline 12 & B I 81/19 & $\begin{array}{l}\text { Ismail Bin Sainul } \\
\text { Minak Rj Sumo }\end{array}$ & $\begin{array}{l}\text { Dusun III Rt01/02 Bungkuk, Marga } \\
\text { Sekampung Kab.Lampung Timur }\end{array}$ & $\begin{array}{l}\text { Lampung Timur, } \\
09 / 11 / 1992\end{array}$ \\
\hline 13 & B I 82/19 & Imron Bin Kharudin & $\begin{array}{l}\text { Dusun VIII rt 03/08 Bungkuk, Marga } \\
\text { Sekampung, Kab.Lampung Timur }\end{array}$ & $\begin{array}{l}\text { Lampung Timur, } \\
10 / 04 / 1995\end{array}$ \\
\hline 14 & B I 12/19 & $\begin{array}{l}\text { Imam Nugraha } \\
\text { BinRahmat }\end{array}$ & $\begin{array}{l}\text { Kp. Kubang Eceng Rt.02 Rw. } 04 \text {, } \\
\text { Mekarjaya, Padakembang, Kab. } \\
\text { Tasikmalaya }\end{array}$ & $\begin{array}{l}\text { Kab. Tasikmalaya, } \\
09 / 09 / 1994\end{array}$ \\
\hline 15 & BI 177/19 & $\begin{array}{l}\text { Tetep Ibnu Abas Bin } \\
\text { Solih Turmudi }\end{array}$ & $\begin{array}{l}\text { Kp. Bengkok I Rt.04/10, Sukalaksana, } \\
\text { Bungursari, Kota Tasikmalaya }\end{array}$ & $\begin{array}{l}\text { Tasikmalaya, } \\
08 / 08 / 1986\end{array}$ \\
\hline 16 & B I 120/19 & $\begin{array}{l}\text { Asep Somantri Bin } \\
\text { Entar }\end{array}$ & $\begin{array}{l}\text { Kp. Cipinaha Rt.22/06, Cipatujah, } \\
\text { Cipatujah, Kab. Tasikmalaya }\end{array}$ & $\begin{array}{l}\text { Tasikmalaya, } \\
01 / 02 / 1994\end{array}$ \\
\hline 17 & B I 165/19 & Ropik Bin Daya & $\begin{array}{l}\text { Kp. Bihbul kaler Rt.05/02, Cikadongdong, } \\
\text { Bojongasih, Kab. Tasikmalaya }\end{array}$ & $\begin{array}{l}\text { Tasikmalaya, } \\
12 / 08 / 1986\end{array}$ \\
\hline 18 & B II A 122/19 & $\begin{array}{l}\text { Rianto Bin Tariat } \\
\text { (Alm) }\end{array}$ & $\begin{array}{l}\text { Kp. Cipari Rt.01/03, Sukamurni, Cilawu, } \\
\text { Garut }\end{array}$ & $\begin{array}{l}\text { Garut, } \\
01 / 07 / 1980\end{array}$ \\
\hline 19 & B I 187/19 & $\begin{array}{l}\text { Sahrul Gunawan Bin } \\
\text { Ani Rosyani }\end{array}$ & $\begin{array}{l}\text { Kp. Depok Rt.01/05, Sukamenak, } \\
\text { Purbaratu, Kota Tasikmalaya }\end{array}$ & $\begin{array}{l}\text { Tasikmalaya, } \\
29 / 12 / 1999\end{array}$ \\
\hline 20 & B I 191/19 & $\begin{array}{l}\text { Dedi Putra Nanda } \\
\text { Bin Kardinal Munir }\end{array}$ & $\begin{array}{l}\text { Lingkungan Babakan Rt. } 03 \text { Rw. } 05 \\
\text { Sindangrasa, Ciamis Kab. Ciamis }\end{array}$ & $\begin{array}{l}\text { Jakarta, } \\
16 / 08 / 1988\end{array}$ \\
\hline
\end{tabular}

Sumber: Lembaga Pemasyarakatan Kelas IIB Kota Tasikmalaya 
Tabel 2. Hasil Wawancara Responden

\begin{tabular}{|c|c|}
\hline Nama & Keterangan \\
\hline Responden 1 & $\begin{array}{l}\text { Merupakan narapidana residivis pencurian, barang yang dicuri adalah Handphone, } \\
\text { pertama kali mencuri pada tahun di tahun } 2016 \text { masa hukuman } 11 \text { bulan, lalu } \\
\text { mengulanginya kembali pada tahun } 2019 \text { masa hukuman } 1 \text { tahun } 5 \text { bulan. Responden } \\
\text { sebelumnya memiliki pekerjaan sebagai buruh bangunan, pendidikan terakhir sebagai } \\
\text { lulusan SD. Keluarga tidak memperdulikan responden karena sudah tidak mau mengatur } \\
\text { dan mengurus responden kembali dan keluarga tidak ada yang membesuk di karenakan } \\
\text { orangtua sudah tua dan responden belum menikah. Menurut responden faktor pemicu } \\
\text { tindakan pencuriannya yaitu tuntutan kebutuhan akan ekonomi. }\end{array}$ \\
\hline Responden 2 & $\begin{array}{l}\text { Merupakan narapidana residivis pencurian, barang yang dicuri adalah padi. Pertama kali } \\
\text { melakukan pencurian pada tahun } 2016 \text { masa hukuman } 11 \text { bulan, dan melakukan } \\
\text { pencurian kembali pada tahun } 2019 \text { masa hukuman } 1 \text { tahun } 5 \text { bulan. Sebelumnya } \\
\text { responden bekerja sebagai buruh serabutan di pasar, pendidikan terakhir SD. Tanggapan } \\
\text { keluarga atas perbuatan responden yaitu bahwa keluarga menyayangkan perbuatan } \\
\text { responden keluarga merasa kecewa terhadap responden sehingga baik orangtua dan istri } \\
\text { beserta anaknya tidak pernah membesuk, bahkan responden tidak memberitahu anaknya } \\
\text { bahwa dirinya di penjara. Alasan responden melakukan pencurian yaitu karena } \\
\text { kebutuhan ekonomi dan terkadang jika melihat barang yang berharga dan peluang yang } \\
\text { besar responden merasa tertarik melakukan pencurian. }\end{array}$ \\
\hline Responden 3 & $\begin{array}{l}\text { Merupakan narapidana residivis pencurian, barang yang dicuri adalah ayam dan motor. } \\
\text { Responden pertama kali melakukan pencurian pada tahun } 2016 \text { masa hukuman } 11 \text { bulan } \\
\text { dan melakukannya kembali pada tahun } 2018 \text { masa hukumannya } 1 \text { tahun } 5 \text { bulan. } \\
\text { Sebelumnya responden bekerja wirausaha catering dan supir angkot, pendidikan terakhir } \\
\text { lulusan SD. Tanggapan keluarga terhadap perbuatan responden bahwa keluarga } \\
\text { responden masih menerima responden meskipun awalnya sangat kecewa, tetapi orangtua } \\
\text { masih menerima responden dan sering membesuk responden selama di Lembaga } \\
\text { Pemasyarakatan. Responden sudah menikah tetapi istri dan anaknya tidak pernah } \\
\text { membesuk, bahkan istri responden meminta cerai karena kecewa dengan perbuatan } \\
\text { responden. Alasan responden melakukan pencurian berulang yaitu karena tuntutan } \\
\text { ekonomi. }\end{array}$ \\
\hline Responden 4 & $\begin{array}{l}\text { Merupakan narapidana residivis pencurian, barang yang dicuri adalah sepeda motor. } \\
\text { Pertama kali melakukan pencurian pada tahun } 2018 \text { masa hukuman } 10 \text { bulan, dan } \\
\text { melakukan pencurian kembali pada tahun } 2019 \text { masa hukumannya } 1 \text { tahun } 4 \text { bulan. } \\
\text { Sebelumnya responden bekerja sebagai supir angkutan umum, pendidikan terakhir SMP. } \\
\text { Responden sudah menikah dan memiliki anak. Tanggapan keluarga terhadap perbuatan } \\
\text { responden bahwa keluarga masih menerima responden dan masih sering membesuk } \\
\text { responden selama di Lembaga pemasyarakatan. Alasan responden melakukan pencurian } \\
\text { adalah untuk memenuhi kebutuhan keluarga, serta biaya sekolah anak-anaknya. }\end{array}$ \\
\hline Responden 5 & $\begin{array}{l}\text { Merupakan narapidana residivis pencurian, barang yang dicuri adalah uang, pertama kali } \\
\text { melakukan pencurian pada tahun } 2016 \text { masa hukuman } 11 \text { bulan, dan melakukan } \\
\text { pencurian kembali pada tahun } 2019 \text { masa hukumannya } 1 \text { tahun } 5 \text { bulan. Sebelumnya } \\
\text { responden bekerja sebagai buruh serabutan, pendidikan terakhir SD. Tanggapan keluarga } \\
\text { terhadap perbuatan responden bahwa orangtua, istri, dan anak merasa kecewa terhadap } \\
\text { perbuatan responden, tetapi keluarga masih menerima responden dan sering dibesuk. } \\
\text { Alasan responden melakukan perbuatan pencurian berulang yaitu faktor ekonomi. }\end{array}$ \\
\hline
\end{tabular}

Sumber: Lembaga Pemasyarakatan Kelas IIB Kota Tasikmalaya

Pernyataan responden di atas, sesuai dengan keterangan yang dijelaskan oleh Bapak Lucky Septian Daryana selaku staff pengelola system database di Lembaga Pemasyarakatan Kota Tasikmalaya, bahwa salah satu faktor terjadinya residivis pencurian karena adanya faktor eksternal dari masyarakat. Narapidana yang telah menjalani masa tahanannya dan keluar dari Lembaga Pemasyarakatan terkadang selalu dicap sebagai "Maling", dan stigma penjahat tidak hilang begitu saja dari masyarakat. Mantan narapidana seringkali kesulitan untuk berbaur dan kembali di masyarakat. Cibiran dari masyarakat inilah yang membuat mantan narapidana merasa bahwa dirinya telah kehilangan jati diri, penolakan yang terjadi dalam masyarakat mendorong mereka untuk melakukan tindak pidana pencurian kembali. ${ }^{12}$ Pernyataan tersebut dapat dianalisa berdasarkan teori penyebab terjadinya kejahatan yang dalam ilmu

12 Wawancara dengan Bapak Lucky Septian Daryana, selaku Staff Pengelola System Database Lembaga Pemasyrakatan Kota Tasikmalaya, Tgl 30 Januari 2019. 
kriminologi dikenal dengan Teori Labeling. Teori labeling mengidentifikasikan seseorang yang sebelumnya melakukan kejahatan akan diberi label sesuai dengan kejahatan yang dilakukannya. Teori ini juga mengidentifikasi bahwa perbuatan jahat tersebut terbentuk karena adanya reaksi sosial yang menuntun seseorang melakukan kejahatannya kembali. ${ }^{13}$

Faktor lain yang menyebabkan responden melakukan tindak pidana berulang yaitu faktor psikologi kriminal, dimana responden merasa tertarik dengan suatu barang dan ingin memilikinya. Gambaran tersebut sebagaimana yang terjadi pada responden 2, yang menyatakan bahwa dirinya tertarik jika melihat barang yang memiliki harga dan peluang yang tinggi. Faktor penyebab terjadinya pencurian juga dapat di lihat dari teori konflik. Teori ini dipengaruhi oleh konflik kepentingan antar kelompokkelompok yang berbeda yang didasarkan pada ketidakmerataan distribusi sumber-sumber langka, seperti pangan, sandang, papan, dan adanya ketidakmerataan kebutuhan oleh pemerintah yang menyebabkan pemberontakan dari masyarakat sehingga terbentuk perilaku jahat, seperti pencurian.

\subsection{Pembinaan Terhadap Narapidana Residivis Pencurian di Lembaga Pemasyarakatan Kelas IIB Kota Tasikmalaya}

Sistem pembinaan narapidana mengacu pada ketentuan pasal 5 Undang-undang Nomor 12 Tahun 1995 Tentang Pemasyarakatan yang dilaksanakan berdasarkan asas:

1. Pengayoman

"Yang dimaksud dengan pengayoman adalah perlakuan terhadap warga binaan pemasyarakatan dalam rangka melindungi masyarakat dari kemungkinan diulanginya tindak pidana oleh warga binaan pemasyarakatan, juga memberikan bekal hidup kepada warga binaan pemasyarakatan agar menjadi warga yang berguna di dalam masyarakat"

2. Persamaan pelakuan dan pelayanan

"Persamaan pelakuan dan pelayanan adalah pemberian perlakuan dan pelayanan yang sama kepada warga binaan pemasyarakatan tanpa membeda-bedakan orang"

3. Pendidikan dan pembimbingan

"Maksud dari pendidikan dan pembimbingan adalah bahwa penyelenggaraan pendidikan dan bimbingan dilaksanakan berdasarkan Pancasila, antara lain penanaman jiwa kekeluargaan, keterampilan, pendidikan kerohanian, dan kesempatan untuk menunaikan ibadah"

yaitu:

Sebelum adanya pembinaan terhadap narapidana ada beberapa tahapan pembinaan narapidana

1. Tahap awal (masuk s/d 1/3 masa pidana) yaitu tahap di mana sejak narapidana pemasyarakatan masuk ke Lembaga Pemasyarakatan sampai dengan 1/3 masa pidana namun pembinaan yang dilakukan masih dalam tahap pengenalan dan belum optimal. Di sini mereka mengalami masa-masa pengenalan yaitu:

a. Registrasi merupakan kegiatan mencatat informasi yang berhubungan dengan identitas diri narapidana seperti nama, alamat, agama, perkara pidana dan sebagainya.

b. Orientasi merupakan kegiatan dalam pengenalan Lembaga Pemasyarakatan, narapidana pemasyarakatan dikenalkan dengan program-program dan hak-hak serta kewajiban mereka sebagai warga binaan pemasyarakatan.

c. Identifikasi dilakukan bertujuan untuk mencari informasi tentang potensi yang berada dalam diri narapidana pemasyarakatan yang kemudian akan disesuaikan dengan program-program yang dilakukan di Lembaga Pemasyarakatan.

d. Seleksi kegiatan ini bertujuan untuk menyeleksi dan untuk mengelompokkan narapidana pemasyarakatan yang sama menjadi satu.

e. Penelitian pemasyarakatan kegiatan ini digunakan untuk mendapatkan informasi tentang latar belakang narapidana pemasyarakatan sebagai pelengkap kegiatan awal pengenalan sebelumnya dan dapat dijadikan dasar untuk pembinaan berikutnya.

2. Tahap lanjutan pertama (1/3 s/d $1 / 2$ m.p.) tahap di mana narapidana Pemasyarakatan melaksanakan 1/3 masa pidana sampai dengan masa $1 / 2$ pidana. Pada tahap ini mereka meneruskan

${ }^{13}$ Santoso, T. \& Zulfa, E.A. (2001). Kriminologi. Jakarta: Raja Grafarindi Persida. h. 98. 
bimbingan yang telah diberikan pada tahap pertama. Lanjutan kedua (1/2 s/d 2/3 m.p.) pada tahap ini narapidana yang memperoleh penilaian apabila baik sudah dapat diasimilasikan di luar Lembaga Pemasyarakatan sebagai persiapan menjelang ia kembali ke masyarakat luas setelah bebas.

3. Tahap akhir (2/3 m.p. s/d akhir m.p.) Apabila yang bersangkutan telah menjalani $2 / 3$ dari masa pidana serta berkelakuan baik maka dapat diusulkan cuti menjelang bebas, menerima pelepasan bersyarat, kemudian mereka mendapatkan pembinaan integrasi, dan hal ini dilakukan di luar Lembaga Pemasyarakatan. ${ }^{14}$

Pembinaan adalah upaya pendidikan formal maupun non formal yang dilakukan secara sadar, berencana, terarah, teratur, dan bertanggung jawab dalam rangka memperkenalkan, menumbuhkan, membimbing, dan mengembangkan suatu dasar-dasar kepribadiannya seimbang, utuh dan selaras, pengetahuan dan keterampilan sesuai dengan bakat, kecenderungan/keinginan serta kemampuan-kemampuannya sebagai bekal, untuk selanjutnya atas perkasa sendiri menambah, meningkatkan dan mengembangkan dirinya, sesamanya maupun lingkungannya ke arah tercapainya martabat, mutu dan kemampuan manusiawi yang optimal dan pribadi yang mandiri. ${ }^{15}$

Pembinaan terhadap narapidana di Lembaga Pemasyarakatan dilakukan dengan pendekatan yang lebih manusiawi. Usaha pembinaan tersebut didasarkan pada Peraturan Pemerintah Nomor 31 Tahun 1999 tentang Pembinaan dan Pembimbingan Warga Binaan Pemasyarakatan. Pasal 1 angka 1 menjelaskan bahwa Pembinaan adalah kegiatan untuk meningkatkan kualitas ketaqwaan kepada Tuhan Yang Maha Esa, intelektual, sikap dan perilaku, profesional, kesehatan jasmani dan rohani narapidana dan anak didik pemasyaraktan. Kemudian pada Pasal 1 angka 2 dijelaskan bahwa Pembimbingan adalah pemberian tuntunan untuk meningkatkan kualitas ketaqwaan terhadap Tuhan Yang Maha Esa, intelektual, sikap dan perilaku, profesional, kesehatan jasmani dan rohani klien pemasyarakatan. ${ }^{16}$

Pembinaan narapidana residivis pencurian disamakan dengan pembinaan terhadap narapidana pada umumnya yang diatur dalam Peraturan Pemerintah Nomor 58 Tahun 1999 tentang Syarat-syarat dan Tata Cara Pelaksanaan Wewenang, Tugas dan Tanggungjawab Perawatan Tahanan. Dalam Peraturan Pemerintah tersebut mengatur pembinaan terhadap narapidana yang meliputi penempatan narapidana, dan mengatur perawatan narapidana. Lembaga Pemasyarakatan Kelas IIB Kota Tasikmalaya tidak membedakan pembinaan terhadap narapidana residivis dengan narapidana lainnya, dikarenakan faktor tempat yang tidak mencukupi untuk para narapidana sehingga pembinaan terhadap semua narapidana disatukan.

Berdasarkan hasil wawancara dengan Bapak Lucky Septiandaryana selaku staff pengelolaan system database di Lembaga Pemasyarakatan Kelas IIB Kota Tasikmalaya mengatakan bahwasanya penempatan terhadap narapidana residivis pencurian di kota Tasikmalaya digabungkan dengan narapidana tindak pidana lain. Hal ini di karenakan tidak cukupnya ruangan yang ada di lapas itu sendiri. Padahal Penempatan narapidana berdasarkan pasal 7 Peraturan Pemerintah Nomor 58 Tahun 1999 tentang Syarat-syarat dan Tata Cara Pelaksanaan Wewenang, Tugas dan Tanggungjawab Perawatan Tahanan. Peraturan Penempatan tahanan ditentukan berdasarkan penggolongan (a) umur, (b) jenis kelamin, (c) jenis tindak pidana, (d) tingkat pemeriksaan perkara, atau (e) untuk kepentingan tertentu yang sesuai dengan kebutuhan dan perkembangan."

Berdasarkan peraturan tersebut, narapidana residivis termasuk dalam pasal 7 huruf (e) "untuk kepentingan tertentu yang sesuai dengan kebutuhan dan perkembangan". Dalam penjelasan Peraturan Pemerintah Nomor 58 Tahun 1999 tentang Syarat-syarat dan Tata Cara Pelaksanaan Wewenang, Tugas dan Tanggungjawab Perawatan Tahanan. Pasal 7 huruf (e) menjelaskan bahwa yang dimaksud dengan "kepentingan tertentu adalah yang berhubungan dengan keperluan penanganan secara khusus, misalnya terhadap pemakai narkotika, tahanan yang diperkirakan mempunyai kelainan jiwa, tahanan kebangsaan asing dan lain-lain yang memerlukan penanganan secara khusus. Sama halnya terhadap narapidana residivis yang memerlukan kebutuhan tertentu dalam hal pembinaannya, sehingga dapat melakukan

\footnotetext{
${ }^{14}$ Khotimah, K. (2016). Proses Pembinaan Warga Binaan Pemasyarakatan di Lembaga Pemasyarakatan Kelas IIA Wirogunan Yogyakarta (Skripsi). Universitas Negeri Yogyakarta. h.103

${ }^{15}$ Simanjuntak. (1990). Membina dan Mengembangkan Generasi Muda. Bandung: Tarsito. h. 84.

${ }^{16}$ Utoyo, M. (2015). Konsep Pembinaan Warga Binaan Pemasyarakatan Analysis of Prisoners Guidance to Reduce Level. Jurnal Ilmu Hukum Pranata Hukum, 10 (1). h. 43.
} 
pembinaan dengan maksimal, dan juga jika narapidana residivis disatukan dengan narapidana lain, ditakutkan akan mempengaruhi narapidana lain dan terjadi kembali pengulangan tindak pidana".

Bapak Lucky Septiandaryana menjelaskan jika pembinaan ingin berjalan secara efektif, maka antara narapidana residivis dengan narapidana lain harusnya dapat dipisahkan karena narapidana residivis adalah pelaku tindak pidana berulang yang di takutkan akan mempengaruhi narapidana lain untuk melakukan tindak pidana berulang. Hal tersebut bertentangan dengan faktanya, bahwa pemisahan yang dilakukan di Lembaga Pemasyarakatan Kelas IIB Kota Tasikmalaya hanya sebatas pemisahan berdasarkan gender saja yaitu antara perempuan dan laki-laki.

Perawatan narapidana residivis juga tidak memiliki peraturan khusus mereka mendapatkan perawatan yang sama dengan narapidana lainnya. Ketentuan tersebut didasarkan pada Peraturan Pemerintah Nomor 58 Tahun 1999 tentang Syarat-syarat dan Tata Cara Pelaksanaan Wewenang, Tugas dan Tanggungjawab Perawatan Tahanan. Ketentuan Pasal 9 Peraturan Pemerintah tersebut berisi "Perawatan tahanan meliputi perawatan jasmanai dan rohani yang dilaksanakan berdasarkan program perawatan". Dan pasal 16 berisi:

(1) Perawatan jasmani dilaksanakan dengan memberikan kegiatan olahraga

(2) Kegiatan olahraga sebagaimana dimaksud dalam ayat (1) berupa olah raga perorangan, permainan dan sejenisnya yang bertujuan untuk menjaga atau meningkatkan kesehatan dan kesegaran fisik

Adapun program perawatan narapidana residivis pencurian Lembaga Pemasyarakatan Kelas IIB Kota Tasikmalaya terdiri dari perawatan jasmani dan rohani. Perawatan jasmani yang dilakukan, yaitu :17

a. Olahraga. Lembaga Pemasyarakatan Kelas IIB Kota Tasikmalaya memiliki kegiatan rutin setiap harinya yang wajib dilakukan oleh warga binaan di sana yaitu kegiatan senam yang dilakukan pada pukul 9.00 pagi. Kegiatan senam ini dilakukan dalam waktu 30 menit, hal ini dilakukan agar narapidana di Lembaga Pemasyarakatan Kelas IIB Kota Tasikmalaya tetap sehat. Selain senam, Lembaga Pemasyarakatan Kelas IIB Kota Tasikmalaya juga memiliki lapangan yang dapat dipakai untuk olahraga futsal, bulu tangkis dan voli, dan juga terdapat meja untuk tenis meja dan catur.

b. Makan dan Minum

Pasal 28 Peraturan Pemerintah Nomor 58 Tahun 1999 tentang Syarat-syarat dan Tata Cara menjelaskan bahwa:

(1) Setiap tahanan berhak mendapatkan makanan sesuai dengan peraturan perundangundangan yang berlaku.

(2) Tahanan warga negara asing, diberikan makanan yang sama seperti tahanan yang lainnya, kecuali atas petunjuk dokter dapat diberikan makanan jenis lain sesuai dengan kebiasaan di negaranya yang harganya tidak melampaui harga makanan seorang sehari.

(3) Setiap tahanan yang sakit, hamil, atau menyusui berhak mendapat makanan tambahan sesuai dengan petunjuk dokter.

(4) Anak dari tahanan wanita yang dibawa ke dalam RUTAN/Cabang RUTAN atau LAPAS/Cabang LAPAS diberi makanan dan makanan tambahan sesuai dengan petunjuk dokter paling lama sampai anak berumur 2 (dua) tahun.

(5) Dalam hal anak sebagaimana dimaksud dalam ayat (4) telah berumur 2 (dua) tahun harus diserahkan kepada bapak atau sanak keluarganya, atau pihak lain atas persetujuan ibunya

Sedangkan pasal 29 menjelaskan bahwa :

(1) Petugas RUTAN/Cabang RUTAN atau LAPAS/Cabang LAPAS yang mengelola makanan bertanggung jawab atas:

a. kebersihan makanan dan dipenuhinya syarat-syarat kesehatan makanan dan gizi

b. pengadaan, penyimpanan, dan penyiapan makanan; dan

c. pemeliharaan peralatan makanan dan peralatan masak

\footnotetext{
${ }^{17}$ Wawancara dengan Bapak Agus Habibuloh, S.E selaku Kepala Sub Seksi Perawatan Napi/Anak Pidana di Lembaga Pemasyrakatan Kota Tasikmalaya. Tgl 30 Januari 2019.
} 
Mengenai makanan dan minuman yang diberikan oleh Lembaga Pemasyarakatan Kelas IIB Kota Tasikmalaya, sudah sesuai dengan standar gizi nasional. Warga binaan diberi makan sehari 3 kali yaitu pada pukul 07.00, pukul 11.30, dan pukul 15.00. menu yang diberikan juga bervariasi, berikut adalah tabel. 3 yang memaparkan salah satu contoh bahan makanan yang akan diberikan pada warga binaan Kota Tasikmalaya.

Tabel 3.

Daftar Menu Untuk Narapidana Lembaga Pemasyarakatan Kelas lib Kota Tasikmalaya

\begin{tabular}{llcl}
\hline No & Jenis Bahan Makanan & No & Jenis Bahan Makanan \\
\hline 1. & Beras untuk pria dewasa & 11 & Kelapa daging \\
2 & Beras untuk wanita dewasa & 12 & Sayuran segar \\
3 & Beras untuk anak & 13 & Bumbu segar \\
4 & Ubi/Ketela & 14 & Garam dapur \\
5 & Ikan Segar & 15 & Gula pasir \\
6 & Ayam ras/builer & 16 & Gula kelapa/Aren \\
7 & Telur ayam ras & 17 & Minyak goring \\
8 & Tempe & 18 & Buah-buahan \\
9 & Tahu & 19 & Racikan Sambal \\
10 & Kacang Hijau & 20 & Air Minum \\
\hline
\end{tabular}

Sumber: Lembaga Pemasyarakatan Kelas IIB Kota Tasikamlaya

Narapidana di Lembaga Pemasyarakatan Kelas IIB Kota Tasikmalaya dapat menerima makanan dari keluarga maupun kerabat yang membesuk tetapi hanya makanan saja, narapidana tidak diperbolehkan menerima minuman dari kerabat/keluarga yang membesuk karena ditakutkan dalam air minum dilarutkan bahan yang membahayakan seperti racun, narkotika, dll. ${ }^{18}$

c. Kesehatan

Kesehatan narapidana diatur dalam Pasal 21 Peraturan Pemerintah Nomor 58 Tahun 1999 yaitu:

(1) Setiap tahanan berhak memperoleh pelayanan kesehatan yang layak.

(2) Pada setiap RUTAN/Cabang RUTAN atau LAPAS/Cabang LAPAS disediakan poliklinik beserta fasilitasnya dan ditempatkan sekurang-kurangnya seorang dokter dan tenaga kesehatan lainnya.

(3) Dalam hal RUTAN/Cabang RUTAN atau LAPAS/Cabang LAPAS belum ada tenaga dokter atau tenaga kesehatan lainnya, maka pelayanan kesehatan dapat minta bantuan kepada rumah sakit atau Puskesmas terdekat.

Narapidana di Lembaga Pemasyarakatan Kelas IIB Kota Tasikmalaya, sebelum ditempatkan di sel selalu diperiksa terlebih dahulu mengenai kesehatannya. Hal tersebut untuk mencegah apabila terdapat penyakit yang menular dan berbahaya dari diri narapidana tersebut. Apabila terdapat penyakit kronis atau penyakit yang dapat menular, Lembaga Pemasyarakatan akan menolak narapidana untuk tinggal di sana. Selain pemeriksaan kesehatan sebelum narapidana tinggal di lembaga pemasyarakatan, terdapat cek kesehatan juga yang dilakukan 3 bulan sekali oleh dokter yang terdapat di Lembaga Pemasyarakatan Kelas IIB Kota Tasikmalaya.

\section{d. Kegiatan kerja}

Kegiatan kerja yang dilakukan oleh narapidana di Lembaga Pemasyarakatan Kelas IIB Kota Tasikmalaya meliputi menjahit, membuat kerajinan seperti celengan, dan membuat sandal hotel. Semua pekerjaan yang dilakukan narapidana tersebut bekerjasama dengan pihak luar. Contohnya dalam membuat sandal hotel, Lembaga Pemasyarakatan Kelas IIB Kota Tasikmalaya bekerjasama dengan hotel yang berada di Kota Tasikmalaya untuk pembuatan sandal yang akan dikerjakan oleh narapidana.

Sedangkan untuk perawatan rohani yang dilakukan Lembaga Pemasyarakatan Kelas IIB Kota Tasikmalaya terhadap narapidananya meliputi:

${ }^{18} \mathrm{Ibid}$, 
a. Ibadah

Kegiatan beribadah di Lembaga Pemasyarakatan Kelas IIB Kota Tasikmalaya sudah sesuai dengan pasal 11 Peraturan Pemerintah Nomor 58 Tahun 1999 tentang Syarat-syarat dan Tata Cara Pelaksanaan Wewenang, Tugas dan Tanggungjawab Perawatan Tahanan yang berisi:

(1) Setiap tahanan berhak melakukan ibadah sesuai dengan agama dan kepercayaannya masingmasing di dalam RUTAN/cabang RUTAN dan LAPAS/Cabang LAPAS.

(2) Bagi tahanan dalam RUTAN/cabang RUTAN dan LAPAS/Cabang LAPAS, pelaksanaan ibadah dilakukan di dalam kamar blok masing-masing

(3) Dalam hal tertentu tahanan dapat melaksanakan ibadah bersama-sama di tempat ibadah yang ada dalam dalam RUTAN/cabang RUTAN dan LAPAS/Cabang LAPAS.

Narapidana di Lembaga Pemasyarakatan Kelas IIB Kota Tasikmalaya sudah disediakan kegiatan keagamaan. Contohnya bagi narapidana beragama Islam selain melakukan shalat 5 waktu juga terdapat kegiatan keagamaan seperti pengajian tafsir yang dilakukan pada hari Senin, hari Rabu, dan hari Jumat, sementara untuk pengajian umum dilakukan pada hari Selasa dan hari Kamis. Perbedaannya jika pengajian tafsir narapidana diajak untuk menerjemahkan kitab suci Al-Quran, sementara pengajian umum berupa ceramah siraman rohani. Sementara bagi narapidana non muslim melakukan kebaktian pada hari Sabtu yang bekerjasama dengan salah satu gereja di Kota Tasikmalaya dan dilakukan di aula serbaguna Lembaga Pemasyarakatan Kelas IIB Kota Tasikmalaya.

\section{b. Pendidikan dan Pengajaran}

Berdasarkan Peraturan Pemerintah Nomor 58 Tahun 1999 tentang Syarat-syarat dan Tata Cara Pelaksanaan Wewenang, Tugas dan Tanggungjawab Perawatan Tahanan pasal 20 menyatakan:

(1) Bagi tahanan dapat diberikan kesempatan mengikuti pendidikan dan pengajaran

(2) Pelaksanaan pendidikan dan pengajaran bagi tahanan sebagaimana dimaksud dalam ayat (1) dapat berupa:

a. Penyuluhan hukum

b. Kesadaran berbangsa dan bernegara, dan

c. Lainnya sesuai dengan program perawatan tahanan.

Ilmu pengetahuan yang diberikan di Lembaga Pemasyarakatan Kelas IIB Kota Tasikmalaya hanya sebatas penyuluhan yang dilakukan oleh Organisasi Masyarakat seperti penyuluhan Hukum, Kesehatan Dll. Biasanya terdapat pendidikan yang diberikan oleh Dinas pendidikan kepada narapidana Lembaga Pemasyarakatan Kelas IIB Kota Tasikmalaya, tetapi saat ini terputus hubungan dengan Dinas Pendidikan dan belum memperbaikinya kembali.

\section{Simpulan}

Berdasarkan penelitian dan analisa yang dilakukan di Lembaga Pemasyarakatan Kelas IIB Kota Tasikmalaya ada beberapa faktor yang menyebabkan narapidana menjadi residivis, yaitu karena adanya tekanan kebutuhan hidup sehari-hari, untuk memenuhi kebutuhan ekonomi keluarganya, untuk sekolah anak dan lain sebagainya. Di samping adanya faktor ekonomi, terdapat pula faktor lingkungan, karena mereka merasa telah di cap sebagai "pencuri" di lingkungan sekitarnya, sehingga narapidana merasa dirinya tidak diterima di masyarakat dan lebih memilih melakukan tindak pidana pencurian kembali. Dan juga faktor lainnya di mana tidak adanya pemerataan kebutuhan yang diberikan oleh pemerintah sehingga dapat menimbulkan pencurian. Narapidana residivis selama menjalani proses pembinaan di Lembaga Pemasyarakatan Kelas IIB Kota Tasikmalaya tidak mendapatkan pembinaan khusus. Pembinaan dilakukan sama dengan narapidana umumnya misalnya seperti penempatan narapidana yang digabungkan karena keterbatasan ruangan. Perawatan narapidana yang meliputi jasmani dan rohani, perawatan jasmani dilakukan dengan adanya kegiatan olahraga seperti senam, futsal, bulu tangkis, tenis meja, dan catur, cek kesehatan narapidana yang dilakukan 3 bulan sekali, makanan yang bergizi dan memiliki bahan baku yang sesuai standar nasional, dan kegiatan kerja di mana narapidana dapat melakukan pekerjaan yang disediakan seperti membuat celengan dan membuat sandal hotel. Sementara perawatan rohani bagi narapidana, Lembaga Pemasyarakatan Kelas IIB Kota Tasikmalaya telah memberikan jadwal untuk melakukan kegiatan ibadah, kegiatan pengajian tafsir dan pengajian umum 
untuk warga binaan yang beragama islam, dan beribadat di aula serbaguna yang bekerja sama dengan salah satu gereja di Kota tasikmalaya setiap hari Sabtu bagi warga binaan non muslim. Kemudian untuk ilmu pengetahuan warga binaan, Lembaga Pemasyarakatan Kelas IIB Kota Tasikmalaya melakukan kerjasama dengan Organisasi Masyarakat untuk melakukan sosialisasi kepada warga binaan mengenai kesehatan ataupun hal lainnya.

\section{Daftar Pustaka.}

Buku

Adang, Y.A. (2013). Kriminologi. Bandung: Refika Aditama.

Ali,M. (2011). Dasar-dasar Hukum Pidana. Jakarta: Sinar Grafika.

Ilyas, A. (2012). Asas-asas Hukum Pidana. Yogyakarta: Rangkang Education Yogyakarta \& PUKAPIndonesia.

Mertokusumo, S. (2007). Mengenal Hukum Suatu Pengantar. Yogyakarta: Liberty Yogyakarta.

Santoso, T. \& Zulfa, E.A. (2001). Kriminologi. Jakarta: Raja Grafarindi Persida.

Simanjuntak. (1990). Membina dan Mengembangkan Generasi Muda. Bandung: Tarsito

\section{Jurnal}

Afamery, S.S. (2016). Residivis dalam Presfektif Sosiologi Hukum. Jurnal Hukum Volikgeist, 1(1)

Rahmad, A dkk. (2016). Tugas dan Wewenang Lembaga Pemasyarakatan Ambarawa dalam Pembinaan Narapidana Sebagai Wujud Perlindungan Narapidana Sebagai Warga Negara. Diponegoro Law Journal, 5(3).

Utoyo, M. (2015). Konsep Pembinaan Warga Binaan Pemasyarakatan Analysis of Prisoners Guidance to Reduce Level. Jurnal Ilmu Hukum Pranata Hukum, 10 (1).

\section{Skripsi/Tesis}

Andre, K.H. (2019). Peran Kejaksaan dalam Penuntutan Tindak Pidana Pencurian dengan Kekerasan (Skripsi). Universitas Lampung, Indonesia.

Khotimah, K. (2016). Proses Pembinaan Warga Binaan Pemasyarakatan di Lembaga Pemasyarakatan Kelas IIA Wirogunan Yogyakarta (Skripsi). Universitas Negeri Yogyakarta, Indonesia.

\section{Regulasi}

Undang-undang Nomor 1 Tahun 1946 KUHP

Undang-undang Nomor 12 Tahun 1995 tentang Pemasyarakatan

Peraturan Pemerintah Nomor 31 Tahun 1999 Tentang Pembinaan dan Pembimbingan Warga Binaan Pemasyarakatan

Peraturan Pemerintah Nomor 58 Tahun 1999 tentang Syarat-Syarat dan Tata Cara Pelaksanaan Wewenang, Tugas dan Tanggungjawab Perawatan Tahanan

Putusan Pengadilan Negeri Tasikmalaya Nomor: 223/Pid.B/2019/Pn.Tsm.

\section{Website}

Badan Pusat Statistik. Statitik Kriminal. (2018). Diakses pada tanggal 10 Oktober 2019, https://www.bps.go.id/publication/download.html, 